\title{
SURASTRI KARMA TRIMURTI: MENGGUGAT HAK-HAK KAUM BURUH PEREMPUAN INDONESIA TAHUN 1945-1954
}

Giana Fitri Indraswari, Leli Yulifar

Universitas Pendidikan Indonesia

\begin{abstract}
This research is entitled "Surastri Karma Trimurti: Sued the Right of Woman Laborers of Indonesia 1945-1954". This research is the interest of author in the role of $S$.K Trimurti in defending the rights of women laborers in Indonesia in 1945-1954. The purpose of this research are, 1) Describe the the social-economic woman laborers in Indonesia 1930-1944; 2) Describe the background of S.K Trimurti's life; 3) Describe how was the efforts of S.K Trimurti for the right of Indonesian woman laborers in 1945-1954; 4) Describe the impact of $S . K$ Trimurti's struggled on the rights of indonesian woman laborers 1948-1954. This research using the History Method, there are: Heuristics, Critics, and Historiography. The research technic which is used in this paper is literature study by using the relevant books. Based on th research, there was few results. First, The condition of woman laborers during the Dutch and Japanese occupations showed injustice, The condition of women workers is still very apprehensive with various actions that are inconsistent with the dignity of women workers as laborers. Second, some activists who fought for the rights of women laborers as one of the workers were S.K Trimurti who had contributed to the fight before and after independence. Third, the efforts of S.K Trimurti were demonstrated for the welfare and prosecution of justice for women laborers in Indonesia, especially regarding wages and reproductive rights. Fourth is the impact of the struggle was contained in the Work Act of 1948 even until now a legal guideline in the field of labor. Keywords: Surastri Karma Trimurti, Woman Laborers, Work Act of 1948
\end{abstract}

ABSTRAK
Penelitian ini berjudul "Surastri Karma Trimurti:

Penelitian ini berjudul "Surastri Karma Trimurti:
Menggugat Hak-Hak Kaum Buruh Perempuan Indonesia Tahun 1945-1954". Penelitian ini merupakan salah satu bentuk ketertarikan penulis mengenai peranan S.K Trimurti dalam membela hak-hak kaum buruh perempuan di Indonesia tahun 1945-1954. Tujuan dari penelitian ini adalah 1) Mendeskripsikan keadaan ekonomisosial kaum buruh perempuan di Indonesia tahun 1930-1944; 2) Memperoleh gambaran mengenai latar belakang kehidupan S.K Trimurti; 3) Mendeskripsikan upaya S.K Trimurti dalam memperjuangkan hak-hak kaum buruh perempuan di Indonesia tahun 1945-1954; 4) Mengetahui dan mendeskripsikan dampak dari perjuangan S.K Trimurti terhadap hak-hak kaum buruh perempuan di Indonesia pada tahun 1948-1954. Adapun metode yang digunakan adalah metode historis dengan melakukan tiga langkah penelitian yakni heuristik, kritik dan historiografi. Sedangkan teknik pengumpulan data yang digunakan ialah studi literatur berupa buku, surat kabar, majalah serta menggunakan sumber lainnya yang dapat menunjang penulisan ini. Berdasarkan hasil penelitian, penulis mengambil intisari bahwa pertama, saat penjajahan bangsa asing yakni Hindia Belanda dan Jepang kondisi buruh perempuan masih sangat memprihatinkan dengan berbagai tindakan-tindakan yang tidak sesuai dengan harkat dan martabat buruh perempuan sebagai buruh. Kedua, dengan kondisi seperti itulah maka memunculkan beberapa aktivis yang memperjuangkan hak-hak buruh perempuan sebagai pekerja salah satu ialah S.K Trimurti yang telah turut andil dalam masa perjuangan sebelum dan setelah kemerdekaan. Ketiga, upaya yang dilakukan S.K Trirmurti ini nyata ditunjukan untuk kesejahteraan serta menegakaan keadilan bagi kaum buruh perempuan di Indonesia terutama mengenai upah dan hak reproduksi. Keempat ialah dampak perjuangannya tersebut tercantum dalam Undang-Undang Kerja tahun 1948 bahkan hingga saat ini menjadi pedoman hukum di bidang perburuhan.

Kata Kunci: Surastri Karma Trimurti, Buruh Perempuan, Undang-Undang Kerja tahun 1948.

Author correspondence

Email: giana.fitri@yahoo.co.id

Available online at http: // http://ejournal.upi.edu/index.php/factum 


\section{PENDAHULUAN}

Dalam Undang-Undang Nomor 13 Tahun 2003, pekerja/buruh merupakan setiap orangyang bekerja dengan menerima upah atau imbalan dalam bentuk lain. Namun di Indonesia sendiri, seringkali buruh dikonotasikan sebagai pekerja rendahan, hina dan lain-lain. Termasuk didalamnya ialah para buruh perempuan disamping buruh laki-laki. Pekerjaan yang awalnya hanya perempuan lakukan di limgkungan keluarga saja, namun dengan terdesaknya pemenuhan kebutuhan perekonomian maka perempuan ikut terjun sebagai pekerja. Secara kodrati, perempuan akan melakukan fungsi-fungsi reproduksiyang berbeda dengan kaum lakilaki. Hal tersebut akan terlihat secara fisik dari keduanya. Perempuan dapat hamil, melahirkan, haid, bahkan menggugurkan sehingga cenderung memiliki kekuatan fisik yang lemah.

Kelemahan yang dimiliki oleh buruh perempuanharusmenjadiperhatiankhusus di lingkungan kerja. Perempuan adakala lemah badannya jika ketika memenuhi kodrat alamnya, misalnya saat hamil, melahirkan anak atau gugur kandung, dan saat haid. Kemudian seringkali perempuan mendapat perlakukan yang tidak menyenangkan saat bekerja atau tindak asusila. Kelemahan yang dimiliki akan mempengaruhi pembelaan diri dari bahaya serangan fisik. Hal-hal tersebut melekat pada perempuan dan seringkali diabaikan oleh para pemegang kekuasaan di lingkungan kerja. Mengenai upah sendiri dijelaskan oleh Hera (2015, hlm. 22) bahwa, nominal gaji yang diterima buruh lelaki lebih besar dibanding buruh perempuan. Alasan di balik fenomena ini ialah perempuan memilih pekerjaan paruh waktu dan pekerjaan yang lebih ringan dibanding lelaki atau pekerjaan yang dilakukan bersamaan dengan kegiatan rumah tangga. Pekerjaan paruh waktu banyak terdapat di industri batik.

Kasus perempuan yang dipekerjakan terjadi pada tahun 1930-an yang dikenal dengan kasus Lasem. Kasus tersebut merupakan kasus perburuhan yang menimpa buruh perempuan industri batik. Berdasarkan pada laporan yang dibuat oleh kantor tenaga kerja pada tahun 1931, telah terjadi eksploitasi buruh perempuan yang cukup luas dengan gaji yang sangat kecil. Para buruh perempuan ini mayoritas buruh luar yang selain digaji dengan upah yang sangat kecil juga dikenai denda yang sangat besar jika melakukan kesalahan. Belum lagi mengenai hak-hak reproduktif yang seringkali diabaikan. Sehingga dari hal tersebut maka pemenuhan hak-hak buruh wantia seperti cuti haid, cuti melahirkan dan hak-hak reproduktif lainnya selalu menjadi stimulus perlawanan buruh perempuan. (Wieringa, 1999, hlm. 140141).

Adanya ketidakadilan yang nampak dengan jelas pada buruh-buruh perempuan membuat geram seorang tokoh perempuan yang hidup pada masa-masa perjuangan rakyat Indonesia. Bahkan ia menjadi saksi hidup atas pembacaan teks Proklamasi oleh Soekarno tahun 1945. Ia adalah Surastri Karma Trimurti atau S.K Trimurti. Upaya yang dilakukan tentu saja melalui berbagai gagasan-gagasan serta ide yang dicurahkan olehnya dalam setiap kesempatan yang berkaitan dengan pembelaan kedudukan perempuan dalam ketenagakerjaan. Penelitian inii berupaya untuk menguraikan peranan tokoh perempuan yang minim ditulis serta 
permasalan mengenai buruh perempua yang masih jarang dikemukakan. Penulisan sejarah mengenai buruh perempuan yang mengalami ketidakberimbangan dengan tulisan-tulisan lainnya akan dibuat mainstream dengan adanya tulisan ini. Diharapkan dengan adanya penelitian ini wacana mengenai perempuan akan kaya. Selain itu pula karya ilmiah ini berguna untuk melengkapi ruang kosong penulisan mengenai perempuan dengan berdasarkan perspektif perempuan pula.

Dalam menunjang penulisan, penulis menggunakan sumber berupa buku, surat kabar, majalah, serta sumber lainnya sebagai kajian pustaka. Hal tersebut dilakukan agar penulis dapat mengembangkan landasan berpikir dalam mengkaji dan menganalisis permasalahan mengenai sejarah politik Indonesia dalam bidang perburuhan, khususnya ialah peranan tokoh politik wanita Indonesia yaitu S.K Trimurti sebagai salah satu aktivis buruh perempuan Indonesia. Adapun tujuan yang ingin dicapai dalam penelitian ini adalah:

1. Mendeskripsikan keadaan ekonomisosial kaum buruh perempuan di Indonesia tahun 1930-1944.

2. Memperoleh gambaran mengenai latar belakang kehidupan S.K Trimurti.

3. Mendeskripsikan upaya S.K Trimurti dalam memperjuangkan hak-hak kaum buruh perempuan di Indonesia tahun 1945-1954.

4. Mengetahui dan mendeskripsikan dampak dari perjuangan S.K Trimurti terhadap hak-hak kaum buruh perempuan di Indonesia pada tahun 1948-1954.
Penelitian ini juga memiliki beberapa manfaat yang diantaranya adalah:

1. Secara teoritis, karya ilmiah ini diharapkan akan memiliki fungsi edukatif yakni memberikan pembelajaran dari peristiwa masa lalu kaitannya dengan perjuangan S.K Trimurti dalam menuntut hak-hak kaum buruh perempuan di Indonesia.

2. Sedangkan kegunaan praktis ialah karya ilmiah ini akan memberikan kontribusi sebagai pelengkap tulisan sejarah politik terlebih mengenai kiprah tokoh perempuan Indonesia. Dengan kata lain penelitian ini merupakan upaya pendokumentasian sebagai referensi bagi yang ingin mengetahui sejarah S.K Trimurti dalam memperjuangan hak-hak kaum buruh perempuan di Indonesia pada kurun waktu tersebut. Pada sisi lain dengan diuraikannya berbagai hal mengenai pemenuhan hak-hak buruh perempuan yang penting adanya kiranya dapat dijadikan bagi pihak terkait dalam membuat kebijakankebijakan yang berkaitan dengan hakhak buruh perempuan di Indonesia.

\section{METODE PENELITIAN}

Metodehistorisadalah prosespenyajian dan analisis secara kritis terhadap rekaman serta peninggalan masa lampau dan menuliskan hasilnya berdasarkan fakta yang telah diperoleh yang terdapat dalam historiografi (Gottshalk, 1969, hlm. $32)$. Lebih jauh Ismaun (2005, hlm. 34) menjelaskan mengenai metode sejarah ialah rekonstruksi imajinatif tentang gambaran masa lampau peristiwaperistiwa sejarah secara kritis dan analitis berdasarkan bukti-bukti dan 
data peninggalan masa lampau yang disebut sumber sejarah. Pendapat lainnya ialah menurut Edson (dalam Supardan, 2011, hlm. 306) dimana metode historis merupakan langkah-langkah, "define the problems or questions to be investigated; search for sources of historical facts; summarize and evaluated the historical sources; and present the pertinent facts within an interpretative framework.

Dari beberapa pemahaman mengenai metode sejarah, dapat disimpulkan bahwa penelitisejarahharusmemilikikemampuan untuk melaksanakan proses penelitian yang dapat dipertanggungjawabkan. Adapun penulis menggunakan metode penelitian yang dijelaskan oleh Sjamsuddin dalam bukunya Metodologi Sejarah. Tiga langkah penulisan yang diungkapkan oleh Sjamduddin (2012, hlm. 85-155) adalah sebagai berikut:

\section{Heuristik}

Heuristik merupakan sebuah kegiatan mencari sumber-sumber untuk mendapatkandata-dataataumencarimateri sejarah atau evidensi sejarah (Sjamsuddin, 2012, hlm. 86). Kemudian menurut Alian (2012, hlm.7) mengemukakan bahwa heuristik adalah upaya penelitian yang mendalam untuk menghimpun jejak sejarah atau mengumpulkan dokumendokumen agar dapat mengetahui segala bentuk peristiwa atau kejadian-kejadian bersejarah di masa lampau. Pengumpulan sumber yang dilakukan penulis adalah dengan mengumpulkan sumber tertulis yang relevan dengan kajian penulis mengenai peranan S.K Trimurti dalam memperjuangkan hak-hak buruh perempuan Indonenesia yahun 1945-1954, dalam hal ini buku, jurnal, artikel dan data-data lainnya baik dari perpustakaan maupun internet.
Pengumpulan sumber yang dilakukan oleh penulis tidak hanya terpaku kepada pengumpulan sumber mengenai tokoh utama penulis saja, namun penulis juga mencari sumber lain yang dapat membatu dalam proses penulisan ini, seperti sumber mengenai keadaan ekonomi sosial masa sebelum kemerdekaan termasuk keadaan buruh perempuan saat itu, kebijakankebijakan perburuhan perempuan sebelum S.K Trimurti menjabat sebagai menteri, dan konsep-konsep lainnya yang dapat menambah kajian penulis. Hal tersebut dilakukan guna memperkaya kajian yang akan dihasilkan. Adapun teknik pengumpulan data yang digunakan oleh penulis adalah studi literatur atau studi kepustakaan. Studi literautur atau studi kepustakaan merupakan teknik pengumpulan dan analisis suatu materi yang berhubungan dengan topik pembahasan yang relevan dengan kajian penulis. Setelah materi didapatkan dari berbagai literatur, untuk memecahkan masalah penulisan, data-data atau materi yang didapat selanjutnya dibandingkan untuk mendapatkan data yang relevan dan objektif.

\section{Kritik Sumber}

Sebagaiusahauntukmencarikebenaran (truth) sejarawan akan dihadapkan kepada kebutuhan membedakan apa yang benar dan apa yang tidak benar atau palsu. Kemampuan tersebut pada dasarnya harus dimiliki oleh seorang sejarawan, sehingga ketidakbenaran suatu cerita sejarah dapat diminimalisir. Dalam hal ini tentunya penulisan mengenai peranan S.K Trimurti dalam memperjuangkan hak-hak kaum buruh perempua di Indonesia tahun 19451954 mengalami proses kritik sumber baik itu secara internal maupun eksternal. Kritik 
ekternal ialah sebuah proses verifikasi atau pengujian sumber sejarah jika dilihat dari aspek-aspek luarnya. Menurut Sjamsuddin (2012, hlm. 105) menjelaskan bahwa, dengan kritik eksternal maka terdapat suatu proses pengujian terhadap asal-usul dari sumber itu sendiri. Jika menggunakan sumber buku maka penulis berupa untuk memeriksa mengenai nama pengarang, tahun terbit, kota terbit, penerbit dan lain sebagainya agar sumber yang digunakan dapat dipertanggungjawabkan.

Sedangkan kritik yang bersifat internal yakni proses peneliti untuk melihat kelayakan konten dari sumbersumber yang telah didapatkan untuk selanjutnya dijadikan bahan untuk penelitian dan penulisan skripsi. "Kritik dalam untuk menilai kredibilitas sumber dengan mempersoalkan isinya, kemampuan pembuatnya, tanggung jawab dan moralnya" (Ismaun, 2005, hlm 50). Penulis akan mencoba melakukan upaya membandingkan buku-buku yang digunakan oleh penulis dalam mengkaji penelitian ini. Proses tersebut tidak lain guna mendapatkan kebenaran yang dapat dipertahankan. Kritik sumber yang dilakukan oleh penulsi ialah berupa pengkategorian apakah sumber yang didapat termasuk sumber primer ataupun sumber sekunder dan apakah infomasi yang didapatkan bisi dipertanggungjawab atau tidak.

\section{Historiografi}

Tahapterakhirdalam sebuah penelitian ialah sebuah rekonstruksi kembali hasil bacaan kedalam sebuah tulisan yang dapat dipertanggungjawabkan. Dalam ilmu sejarah tahapan ini disebut sebagai historiografi atau penulisan sejarah. Pada bagian ini penulis akan menyajikan hasil temuan-temuan dari sumber-sumber yang telah dikumpulkan, diseleksi melalui kritik sumber, dan rekontruksi secara analitis dan imajinatif berdasarkan faktafakta yang telah ditemukan selama proses penelitian.

\section{HASIL PENELITIAN DAN PEMBAHASAN}

Keadaan Ekonomi-Sosial Kaum Buruh Perempuan di Indonesia Tahun 1930-1944

Indonesia yang saat ini merdeka, telah mengalami perjalanan panjang mengenai penjajahan bangsa asing. Dua bangsa tersebut diantaranya ialah Belanda dan Jepang. Pengaruh serta dampak penjajahan dua bangsa tersebut tentunya dirasakan oleh masyarakat Indonesia pada saat itu, termasuk dalam hal ini ialah dalam aspek ekonomi dan sosial. Aspek ekonomi serta sosial ini tidak dapat dipungkiri memiliki keterkaitan sehingga dalam prosesnya dapat menggambarkan keadaan masyarakat secara menyeluruh. Seperti yang dikatakan oleh Burger (1962, hlm. 4) bahwa, "dalam melukiskan keadaan ekonomi, tidak dapat dihilangkan faktorfaktor sosiologis". Setiap penjajahan sudah tentu menghasilkan suatu keadaan baik ekonomis maupun sosiologis yang berbeda maka untuk menggambarkannya penulis memisahkan sesuai dengan penjajahan dua bangsa yang pernah dialami yakni pemerintahan Hindia Belanda dan Jepang dalam kurun waktu 1930-1944. Pembahasan ini akan memberikan gambaran kepada pembaca mengenai keadaan ekonomi dan sosiologi terutama menimpa perempuan sebelum adanya upaya yang dilakukan oleh beberapa pihak khusunya ialah S.K Trimurti dalam pembelaannya terhadap kaum buruh perempuan. 
Pada masa penjajahan Hindia Belanda perubahan yang terjadi dalam sistem ekonomi saat itu ialah peralihan dari ekonomi yang bersifat komunal dan tradisional menjadi sitem ekonomi yang bebas. Seperti yang dijelaskan dalam Yulianti (2013, hlm. 98).

...karena tahun 1870 diluncurkan Undang-Undang Agraria. U.U. Agraria ini melarang pengambilalihan tanah pribumi oleh orang asing, mereka hanya diijinkan menyewa dalam waktu lima tahun, yang dapat diperpanjang lagi. Untuk perkebunan swasta yang memerlukan lahan luas, penyewaan tanah diijinkan kontrak jangka panjang selama 75 tahun. Kebijakan ini membuat perusahaan perkebunan swata banyak yang menanamkan modal di Hindia Belanda.

Maka dengan sistem tersebut, masyakarat Hindia Belanda dikenalkan dengan peredaran uang serta kerja upah dalam hubungan luas dibawah pimpinan pengusaha partikelir. Hal tersebut yang menyebabkan masyarakat banyak bekerja di perusahaan milik penguasa asing sebagai buruh. Munculnya kaum buruh dijadikan sebagai gambaran keadaan ekonomi Hindia Belanda pada saat itu. Dasawarsa terakhir Hindia Belanda (19301942) perkembangan industri semakin meningkat. Hal tersebut dijelaskan oleh (Poesponegoro \& Notosusanto, 1993, hlm, 84) bahwa di bidang perusahaan khususnya perusahaan perkebunan mengalami suatu perkembangan yang sangat pesat di dasawarsa ketiga penjajahan Belanda. Namun pada antara tahun 1930-1937 Hindia Belanda terkena dampak dari depresi ekonomi dunia yang mengakibatkan banyak buruh yang menganggur akibat pemutusan kerja. Dari pemutusan kerja ini banyak buruh perempuan yang menjadi pengangguran karena diberhentikan bekerja untuk mengurangi beban perusahaan. Hal ini yang nantinya berdampak kepada kehidupan sosial masyarakat Indonesia sendiri terlebih perempuan yang semakin menunjukan kesengsaraan dan ketidakmampuan untuk memenuhi kebutuhan hidup.

Buruh perempuan sendiri pada masa penjajahan Hindia Belanda menjadi salah satu aktor pekerja yang dapat menguntungkan perusahaan-perusahan. Masuknya buruh perempuan tersebut ialah ke beberapa sektor seperti, Sektor yang banyak dimasuki oleh kaum perempuan ialah seperti, tekstil serta tenun batik, lapangan perkebunan, rokok, pertanian dan sebagainya telah memberikan suatu pengalaman sejarah yakni seorang perempuan pun dapat melakukan pekerjaan diluar rumahnya. Memasuki tahun peralihan kekuasaan oleh Jepang, ekonomi difokuskan untuk pemenuhan kebutuhan perang. Berbagai industri dikembangkan, hal ini dijelaskan dalam Larasati (2013, hlm. 16) bahwa titik berat dari pendudukan Jepang ialah mengenai pemenuhan perang yang sedang dilakukan sehingga kondisi tersebut mengakibatkan masyarakat yang mengalami kelaparan serta kemiskinan yang hebat. Industri semua diambil alih oleh Jepang dan pengerahan tenaga-tenaga manusia untuk bekerja pun sangatlah besar, sehingga untuk produksi pangan semakin menurun dan mengakibatkan kesengsaraan berkepanjangan pada rakyat saat itu. Buruh perempuan pun digunakan sebagai mesin penghasil produksi, dikarenakan para laki-laki dikerahkan sebagai romusha. Hal tersebut diuraikan oleh Hera (2015, hlm. 20) bahwa "Selama pendudukan Jepang, kurangnya keseimbangan kehidupan sosial dan ekonomi memaksa perempuan 
menjadi tulang punggung keluarga karena lelaki dimanfaatkan sebagai romusha".

Mengenai kebijakan-kebijakan mengenai perburuhan pada masa penjajahan tersebut, belum dapat melindungi hak-hak buruh terutama buruh perempuan. Mengenai tingkat upah dijelaskan oleh Furnivall (2009, hlm. 377 ) yakni "Tingkat upah aktual tahun 1930 perkebunan tembakau membayar 57, 5 sen untuk laki-laki dan 44 sen untuk perempuan dan di pabrik gula di Jawa membayar 46 sen untuk laki-laki dan 37 sen untuk perempuan". Terlihat bahwa terdapat perbedaan antara buruh perempuan dengan buruh laki-laki pada umumnya. Terlepas dari para buruh perempuan di perkebunan tersebut, dijelaskan dalam Wieringa (1999, hlm. 141) bahwa terdapat kondisi menyedihkan dari buruh kontrak di pabrik Batik Lasem pada tahun 1930 yang menyangkut mengenai eksplotiasi buruh perempuan dan upah yang kecil bagi mereka. Memasuki era baru penjajahan yakni oleh Jepang, kebijakankebijakan mengenai bidang perburuhan belum menunjukan kekhususan terutama bagi buruh perempuan. Adapun badan pengawas tersebut ialah Saibai Kigyo Kanrikodan (SKK) yang bertindak sebagai pengawas dan juga bertindak sebagai pelaksana dari pembelian, penentuan harga, penjualan hasil perkebunan. Begitu pula dengan kegiatan-kegiatan buruh yang bekerja didalamnya. Pemenuhan akan kebutuhan perang memaksa para buruh terutama buruh perempuan giat dalam mempebanyak produksi.

\section{Latar Belakang Kehidupan S.K Trimurti}

Surastri Karma Trimurti atau lebih dikenal sebagai S.K Trimurti merupakan salah satu tokoh perempuan yang pernah berpengaruh di Indonesia. S.K Trimurti adalah pejuang perempuan yang sebagain hidupnya diabdikan kepada bangsanya. Terlebih perhatiannya ditujukan untuk kemajuan para perempuan di Indonesia termasuk didalamnya ialah kaum buruh. Kaum buruh perempuan Indonesia perlu mendapat perhatian lebih terutama dalam pemenuhan hak-haknya sebagai pekerja. Maka dengan itu S.K Trimurti muncul sebagai salah satu tokoh atau lebih disebut sebagai aktivis buruh perempuan. Setiap tingkah laku, gagasan serta ide yang berkaitan dengan perjuangannya terhadap kaum buruh perempuan tentunya dipengaruhi oleh beberapa faktor baik itu faktor intern ataupun ektern seperti latar belakang keluarga, pendidikan ataupun organisasi yang pernah diikuti. Hal tersebutlah yang kemudian menjadikan S.K Trimurti sebagai sosok yang akan peduli adanya ketidakadilan dalam hal ini ialah terhadap kaum buruh perempuan Indonesia.

Lahir pada tanggal 11 Mei 1912 tepat hari Sabtu Kliwon di Desa Sawahan, Boyolali, Keresidenan Surakarta. Pada saat itu daerah kelahiran S.K Trimurti masih termasuk dalam Keresidenan Surakarta dengan Bupati R.T Prawinagaro (Jazimah, 2016, hlm. 2). Lingkungan keluarga dan masa-masa kecil S.K Trimurti dapat dikatakan berkecukupan dikarena ia merupakan anak dari seorang priyayi. Namun hal tersebutlah yang kemudian memunculkan keprihatinan S.K Trimurti kepada anak-anak seumur dia yang tidak sama Lingkungan keluarga dan masamasa kecil S.K Trimurti dapat dikatakan berkecukupan dikarena ia merupakan anak dari seorang priyayi. Namun hal tersebutlah yang kemudian memunculkan keprihatinan S.K Trimurti kepada anak- 
anak seumur dia yang tidak sama baik dilihat dari kemampuan ekonomi maupun status sosial. Pada saat itu memang perbedaan akan terlihat sangat mencolok antar golongan, baik itu para bangsa Eropa, bangsawan sepertinya dan rakyat jelata (wong cilik).

Disaat S.K Trimurti sudah memakai pakaian yang bagus, bersih dan rapi. Kawulo disekitarnya masih banyak yang setengah telanjang, bahkan anak-anak kecil kerap bertelanjang bulat. Hal ini disebabkan karena memang mahalnya harga pakaian, juga pola hidup itu sendiri (Jazimah, 2016, hlm. 5).

Bahkan untuk masalah pendidikan, S.K Trimurti mendapat keuntungan untuk bersekolah dibandingkan dengan anak lainnya. S.K. Trimurti sendiri yang menjadi golongan priyayi dimasukan ke sekolah Ongko Loro atau Tweede Inlandsche School (TIS). TIS ini setara dengan pendidikan dasar saat ini (SD). Dengan bersekolah di TIS setidaknnya S.K Trimurti telah dibuka matanya akan suatu diskriminasi pendidikan. S.K Trimurti termasuk anak yang beruntung karena masih sempat mengeyam pendidikan yang layak, sedangkan anak-anak desa lainnya denngan segala keterbatasan yang dimiliki belum sempat untuk mengecap indahnya pendidikan bahkan di Volksschool (sekolah rendah khusus anak-anak desa) sekalipun. Setelah lulus dari TIS, S.K Trimurti yang menuruti keinginan ayahnya masuk ke Sekolah Guru Putri atau Meisjes Normaal School (MNS) selama 4 tahun lamanya. Sekolah tersebut yang nantinya akan mencetak calon-calon pendidik atau guru. Setelah lulus tahun 1930 dari sekolah guru dengan hasil yang sangat memuaskan maka S.K Trimurti diperbolehkan untuk menjadi guru Sekolah Latihan. Sekolah Latihan sendiri digunakan untuk lulusan MNS yang baru lulus untuk magang dan mengajar disana. Namun karena lingkungan yang tidak sesuai, S.K Trimurti terpaksa pindah mengajar hingga ke Banyumas.

Di Bayumas lah, S.K Trimurti mulai mengecap pengalaman organisasinya hingga pada akhirnya ia menjadi salah soerang tokoh penting yang pernah dimiliki oleh bangsa Indonesia. S.K Trimurti meninggalkan pekerjaannya sebagai pengajar di Banyumas untuk ikut aktif untuk memperjuangkan bangsa dan tanah airnya. Dengan masuk Partindo, diteruskan dengan aktifnya dalam organisasi bentuk Jepang Jawa Hokokai dan Fujinkai, menjadi bagian dari Barisan Buruh Indonesia, mendirikan latihan kader Barisan Buruh Wanita bahkan mendirikan Gerwis yang menjadi cikal Gerwani. Tidak luput jabatan penting yang pernah diemban S.K Trimurti ialah ia menjadi Menteri Perburuhan pertama di Indonesia pada masa kabinet Amir Syarifoedin tahun 1947-1948. Agenda perjuangnnya ialah mengisi kemerdekaan dengan menegakkan keadilan bagi bangsanya. Artinya S.K Trimurti mengingkan keadilan yang merata bagi seluruh rakyat Indonesia termasuk untuk buruh perempuan.

\section{Upaya S.K Trimurti dalam Memperjuangkan Hak-Hak Kaum Buruh Perempuan di Indonesia Tahun 1945-1954}

Keadaan yang memprihatikankan dari buruh perempuan selama penjajahan bangsa asing bahkan setelah Indonesia merdeka membuat S.K Trimurti senantiasa memperjuangkan hak-hak yang seharusnya didapat oleh buruh perempuan sebagai pekerja. Sebagai buruh, perempuan tentunya memiliki peran serta kedudukan yang setara dengan buruh laki-laki baik itu mengenai upah, 
jaminan keselamatan ataupun jaminan kesejahteraan. Tahun 1945 merupakan tahun berdirinya organisasi buruh perempuan yaitu Barisan Buruh Wanita (BBW). BBW didirikan sebagai salah satu organisasi atau badan yang membantu kerja dari Barisan Buruh Indonesia. S.K Trimurti terlibat didalamnya sebagai ketua.

Kalangan buruh perempuan mendirikan Barisan Boeroeh Wanita yang diketuai oleh Trimurti. Kegiatan organisasi ini ditujukan untuk memberi pendidikan dan kesadaran pada kaum buruh perempuan, khususnya arti penting persatuan (Hera, 2015, hlm. 21).

Jazimah (2016, hlm. 149-150) menguraikan proses dari pemberian kursus untuk para perempuan di BBW, yakni S.K. Trimurti memberikan kursus kepada kader-kader BBW di Yogyakarta. Saat BBW mengadakan kongres di Kediri pada tanggal 25-28 Januari tahun 1946, S.K Trimurti turut hadir dan menyampaikan gagasannya mengenai perjuangan buruh terutama buruh perempuan di Indonesia. Hal ini ia tulisakan dalam surat kabar Kedaulatan Rakyat bahwa,

Hal-hal jang choesoes jang lebih doeloe dirasakan oleh boeroeh wanita, misalnja: kekoerangan perlingdoengan terhadap boereoh wanita jangan mengandoeng dan melahirkan anak, kekoerangan perlindoengan dalam hal pendjagaan kehormatan dan kesopanan wanita di tempat-tempat pekerjaannja, tidak adanja tempat-tempat penitipan anak-anak ketjil bagi kaoem boereoh wanita dan lain sebagainja (Trimurti, 24 Januari 1946, hlm. 2).

Ketika pembentukan menteri oleh Amir Syarifoedin, S.K Trimurti terpilih menjadi Menteri Perburuhan pertama dikarenaka kompetensinya dalam menangani permasalahan buruh. Saat itu S.K Trimurti sedang menjabat menjadi ketua PBI (Partai Buruh Indonesia). Selama menjabat sebagai menteri yang dapat dikatakan ialah orang yang memiliki kedudukan tinggi dalam bidang perburuhan, tidak di sia-siakan oleh S.K Trimurti. Upaya perjuangan guna mencapai kesehejahteraan kaum buruh dilakukannya dengan sebaik mungkin. Sehingga dengan berbagai macam kondisi buruh perempuan yang memprihatinkan dalam pengupahan ataupun jaminan reproduksif dan keselamatan maka, S.K Trimurti dengan kementrian perburuhan berhasil menyusun Undang-Undang Kerja No. 12 yang disahkan pada tahun 1948 (Soebagijo, 1985, hlm. 161). Dalam undang-undang tersebut tercantum pasalpasal yang mengatur segala permasalahan tentang buruh dan yang istimewanya ialah mengenai buruh perempuan. Jazimah (2016, hlm. 169) menjelaskan bahwa,

Perhatiannya terhadap pekerja perempuan sangat besar, sehingga Undang-Undang Perburuhan yang baru itu memuat beberapa pasal yang berkaiatan dengan posisi perempuan. Bahkan ia mengeluarkan hak cuti haid bagi buruh perempuan. Perihal ini disampaikan sendiri oleh Kartinah Kurdi, mantan Sekretaris Jendral Gerwani, beliau yang pertama kali menerbitkan ketentuan hak cuti haid bagi buruh perempuan.

Setelah menjabat sebagai menteri, S.K Trimurti pada tahun 1950 menjadi prakarsa didirikannya organisasi Gerakan Wanita Sedar (Gerwis). Sehingga Gerwis dibawah kepemimpinan S.K Trimurti dan lainnya berupaya untuk mendapatkan kedudukan yang setara bagi perempuan. Dengan lahirnya Gerwis sebagai organisasi massa perempuan yang terbesar pada saat itu, maka hal itu dijadikan sebagai momentum yang bagi bagi kesejahteraan perempuan pada khususnya. Organisasi tersebut terus berkembang dan berganti nama menjadi Gerwani hingga pada akhirnya tahun 1954 S.K Trimurti mulai menunjukan ketidakaktifannya sebagai pengurus besar, dan pada akhirnya ia pun keluar dari keanggotaan Gerwani. Hal ini 
disebabkan karena keterlibatan PKI yang sangat besar didalam tubuh Gerwani.

Eksistensi S.K Trimurti masih terlihat dalam perjuangannya membela hak-hak buruh perempuan ialah dengan aktif dalam kegiatan jurnalis. Bahkan ketika bergabung dengan Partindo ia sudah dikenalkan dengan kegiatan tersebut.

Tujuan S.K. Trimurti dalam karya tulisan diatas juga tedapat implementasi pemikiran politikya yaitu untuk membuka hati rakyat Indonesia agar terus dapat berjuang hingga titik darah penghabisan untuk membuka pintu gerbang kemerdekaan. Perjuangan bukan hanya melalui pidato maupun tulisan-tulisan tetapi perjuangan adalah menggabungkan seluruh aspek untuk maju bersama-sama melawan penjajah (Agustina \& Suparwato, 2014, hlm. 256).

Gagasan-gagasan pembelaannya terhadap kaum buruh perempuan, S.K Trimurti tuangkan salah satunya ialah dalam Majalah Wanita. S.K Trimurti kerap menyinggung mengenai pelaksanaan dari Undang-Undang Kerja yang disahkan pada tahun 1948 tersebut.

\section{Dampak Perjuangan S.K Trimurti terhadap Hak-Hak Kaum Buruh Perempuan di Indonesia pada Tahun 1948-1954}

Sebagai salah satu prestasi ketika menjabat sebagai menteri, S.K Trimurti bersama dengan Kementrian Perburuhan berhasil menyusun Undang-Undang dalam Perburuhan yakni Undang-Undang Kerja yang disahkan pada tahun 1948. Undangundang ini akan menjadi pedoman untuk masyarakat pada umumnya, untuk buruh dan majikan pada khususnya. Pasalpasal yang menghimpun akan adanya pembelaan hak-hak buruh perempuan yang telah disusun dalam sebuah buku oleh Koesnodiprodjo (1957, hlm. 10-14). Pada khusunya pasal tersebut mencantumkan hak-hak buruh perempuan sebagai pekerja ialah pada pasal 7,8,9 dan 13. Pasal-pasal tentang pekerjaan buruh perempuan dibuat dengan mempertimbangkan posisi perempuan yang kadangkala lemah badannya ketika melaksanakan kodrat alamnya. Begitu pula dengan keselamatan bekerja, kesehatan serta ancaman kesusilaan yang seringkali menimpa buruh perempuan di tempat kerja. Pasalpasal tersebut menguraikan bahwa buruh perempuan tidak diperbolehkan untuk menjalankan pekerjaan yang berbahaya, baik itu bagi kesehatan, keselamatannya, serta kesusilaannya. Jaminan mengenai istirahat cuti haidh, hamil, melahirkan, menyusui dan yang berkaitan dengan reproduksi perempuan lainnya tercantum dalam pasal dalam UKK tersebut.

Setelah tahun diterbitkannya UndangUndang Kerja tahun 1948 adapun dampaknya, bagi kaum buruh perempuan belum sepenuhnya dirasakan. Jadi masalah setelah diberlakukakannya UndangUndang tersebut maka yang terjadi ialah ketidakadilan gender yang di alami di tempat kerja, hal ini akan berkaitan dengan pengakuan hak-hak buruh perempuan itu sendiri dan perlindungan hukum yang mengikat. Kemudian tercatat pada tahun 1952 berdasarkan dengan Suryomenggolo (2015, hlm. 69-70) pemberian upah kepada buruh perempuan dipabrik-pabrik jika dirata-ratakan untuk Indonesia ialah sebesar Rp. 3, 50 sedangkan buruh lakilaki Rp. 4.oo. Hal tersebut menunjukan bahwa perbedaan upah masih ada hingga tahun itu.

Secara gamblang oleh Trimurti (9 Juni 1950, hlm. 171) bahwa persoalanpersoalan mencakup hak-hak reproduksi menunjukan hal yang menyedihkan di tahun 1950, yakni pengajuan cuti hamil dari buruh perempuan kepada majikan 
tidak disertai dengan uang sedikitpun, bahkan ada yang sampai dikeluarkan dari pekerjaan begitu saja. Dan setelah melahirkan baji akan membutuhkan waktu dengan sang ibu termasuk untuk memberikan ASI kepada anak. Namun pada kenyataannya karena terdapat pemecatan yang dilakukan itulah, ibu segara mencari pekerjaaan lain karena ekonomi rumah tangga yang memaksa untuk melakukan hal itu.

\section{SIMPULAN}

S.K Trimurti ialah salah seorang tokoh perempuan yang sangat amat penting perananannya, terutama dalam pembelaan hak-hak buruh perempuan. Kondisi yang memprihatinkan dari buruh perempuan sejak penjajahan Belanda hingga Jepang, membuat S.K Trimurti merasa perlu untuk memperbaiki kondisi tersebut. Dengan pengalaman-pengalaman yang pernah dilalui, organisasi yang pernah diikuti, dan jabatan yang pernah diberikan kepadanya, memunculkan suatu tindakan perjuangannya terhadap hak-hak buruh perempuan. Undang-Undang Kerja tahun 1948 merupakan bukti nyata hasil dari perjuangan S.K Trimurti berserta kementrian. Bahkan beberapa pasal didalamnya mencantumkan mengenai hak buruh perempuan seperti jam kerja, tidak dibolehkannya buruh perempuan pada malam hari, hingga pemenuhan jaminan cuti haidh, hamil, melahirkan, menyusui dan yang berkaitan dengan reproduksi perempuan lainnya tercantum dalam pasal dalam UKK tersebut.

Maka dari itu perjuangan yang telah dilakukan akan terasa sia-sia jika diteruskan oleh pihak-pihak yang selanjutnya menangani masalah-masalah buruh perempuan. Dengan itu perjuangan tidak dapat dikatakan selesai begitu saja oleh satu orang atau lainnya. Namun dengan proses saling bahu-membahu dari semua pihak baik pemerintah, masyarakat terutama buruh itu sendiri guna mencapai masyarakat yang adil sesuai yang tercantum pada dasar negara. Sehingga dari perjalanan sejarahlah kita dapat belajar bahwa dengan nilai-nilai perjuangan tokoh masa lampau dapat dijadikanan sebagai pedoman perjuangan hari ini dan kedepannya.

\section{DAFTAR PUSTAKA}

Agustina, A. E. \& Suparwoto. (2014). S.K. Trimurti dan Pemikirannya untuk Kemajuan Bangsa Tahun 1933-1962. Avatara, e-Journal Pendidikan Sejarah. 2 (3), hlm. 251-261.

Alian, (2012). Metodologi sejarah dan implementasi dalam penelitian. Diakses dari: http:// eprints.unsri.ac.id/3680/1/1._ METODOLOGI_SEJARAH_DAN_ IMPLEMENTASIN_DALAM _ PENELITIAN.pdf

Burger. (1970). Sedjarah ekonomis sosiologis Indonesia jilid II. Jakarta: Pradja Paramita

Furnivall. (2009). Hindia Belanda studi tentang ekonomi Majemuk. Freedom Institute: Jakarta.

Gottschlak, L. (1986). Mengerti Sejarah. Jakarta : Universitas Indonesia Press.

Hera, F.X.D (2015). Menghadirkan ruang bagi buruh perempuan dalam studi sejarah Indonesia. Peneliti di Pusat Studi Budaya dan Laman Batas, LPPM, Universitas Brawijaya, 9 (1), hlm. 1925.

Ismaun. (2005). Pengatar belajar sejarah sebagai ilmu dan wahana pendidikan. 
Bandung: Historia Utama Press.

Jazimah, I. (2016). S.K Trimurti pejuang perempuan Indonesia. Jakarta: Kompas.

Koesnodiprodjo. (1957). Undang-undang perburuhan dan beberapa aturanaturan pelaksanaannya (bahasa Indonesia dan Belanda). Jakarta: Penerbit S.K Seno Djakarta.

Larasati, C. Z. (2013). Kebijakan Jepang semasa pendudukannya di Indonesia. Skripsi. Fakultas Ilmu Pengetahuan Budaya Program Studi Sastra Jepang, Depok.

Sjamsuddin, H. (2012). Metodologi sejarah. Yogyakarta: Ombak.

Soebagijo, I.N. (1982). S.K Trimurti wanita pengabdi bangsa. Jakarta: PT Gunung Agung.

Supardan, D. (2011). Pengantar ilmu sosial: sebuah kajian pendekatan struktural. Jakarta: Bumi Aksara.

Suryomenggolo, J. (2015). Politik perburuhan era demokrasi liberal 1950an. Jakarta: Marjin Kiri.

Trimurti, S.K. (1946, 24 Januari). Perdjoangan Boeroeh. Kedaulatan Rakjat. hlm. 2
Trimurti, S.K. (1950, 9 Juni). Perlindungan buruh wanita dan anak-anak. Majalah Wanita, hlm. 171-172.

Poeponegoro, M.D., \& Notosusanto, N. (1993). Sejarah nasional Indonesia jilid V. Balai Pustaka: Jakarta.

Wieringa, S. E. (1999). Penghancuran gerakan perempuan Indonesia. Jakarta: Garba Budaya.

Yulianti. (2013). Dampak kebijakan kolonial di Jawa. Jurnal Sejarah dan Budaya. 7 (2), hlm. 96-107.

\section{INDEX AUTHOR}

Jazimah, I. (2016). S.K Trimurti pejuang perempuan Indonesia. Jakarta: Kompas.

Koesnodiprodjo. (1957). Undang-undang perburuhan dan beberapa aturanaturan pelaksanaannya (bahasa Indonesia dan Belanda). Jakarta: Penerbit S.K Seno Djakarta.

Wieringa, S. E. (1999). Penghancuran gerakan perempuan Indonesia. Jakarta: Garba Budaya. 